\title{
Pengembangan Sistem Informasi Pemasaran Produk Pertanian berbasis Website
}

\author{
Veronika Asri Tandirerung ${ }^{1}$, Syahrul $^{1}$, Achmad Padil $^{1}$ \\ ${ }^{1}$ Program Studi Pendidikan Teknik Informatika dan Komputer Universitas Negeri Makassar \\ Email: veronika.asri@unm.ac.id
}

\begin{abstract}
The development of an agricultural product marketing information system is needed to assist farmers in marketing agricultural products, especially in the era of the Covid-19 pandemic. This research is a system development research with a prototype development models with a feasibility study using ISO 9126 standards. The research data is obtained from the results of observations and filling out questionnaires by respondents. The results of application testing are obtained by analyzing aspects of functionality, usability, maintainability, and portability. In the functional aspect, it is in the good category. In the usability aspect, the good category with percentage of $88,13 \%$, so that the application is declared feasible and is well responded to by users. On the aspect of maintainability, this agricultural marketing system can run well. In the aspect of portability, agricultural market application systems can run well. The application of this agricultural product marketing system requires the cooperation of agricultural and UMKM in order to help farmers and UMKM in increasing product sales.
\end{abstract}

Keywords: information system, marketing, agriculture

\begin{abstract}
ABSTRAK
Pengembangan sistem informasi pemasaran produk pertanian dibutuhkan untuk membantu para petani dalam memasarkan produk-produk pertanian khususnya di era pandemic COVID-19. Penelitian ini merupakan penelitian pengembangan sistem dengan model pengembangan prototype dengan studi kelayakan menggunakan standar ISO 9126. Data penelitian diperoleh dari hasil observasi dan pengisian kuesioner oleh responden. Hasil pengujian aplikasi diperoleh dengan menganalisis aspek-aspek pada functionality, usability, maintanability, dan portability. Pada aspek functionality berada pada kategori baik. Pada aspek usability, kategori baik dengan persentase $88,13 \%$, sehingga aplikasi dinyatakan layak dan ditanggapi baik oleh pengguna. Pada aspek maintanbility, sistem pemasaran pertanian ini dapat berjalan dengan baik. Pada aspek portability, aplikasi sistem permasaran pertanian dapat berjalan dengan baik. Penerapan sistem pemasaran produk pertanian ini membutuhkan kerjasama dinas pertanian dan UMKM agar dapat membantu para petani dan pelaku UMKM dalam peningkatan penjualan produk.
\end{abstract}

Kata kunci: sistem informasi, pemasaran, pertanian

\section{PENDAHULUAN}

Indonesia memiliki kekayaan alam yang sangat beragam. Indonesia juga merupakan salah satu negara agraris yang sedang berkembang dan banyak mengekspor hasil pertaniannya ke luar negeri. Salah satu sektor yang sangat berkontribusi dalam pembangunan ekonomi Indonesia adalah sektor pertanian. Beberapa kontribusi pertanian dalam pembangunan ekonomi dalam hal penyerapan tenaga kerja, sumber pendapatan, penyediaan pangan, penyedia bahan baku, dan dalam dalam bentuk kapital [1]. Menurut data BPS 2020, pertanian, kehutanan dan perikanan merupakan bidang pekerjaan dengan distribusi tenaga kerja terbanyak sebesar $29.76 \%$. Tambahan, bidang tersebut merupakan perolehan prosentase peningkatan terbesar sebanyak $2.23 \%$ [2].

Digitalisasi di bidang pertanian merupakan salah satu upaya strategis untuk peningkatan produktivitas pertanian. Hasil studi pada tahun 2015-2019 menunjukkan bahwa penggunaan teknologi menjadi penyebab kenaikan Produk Domestik Regional Bruto (PDRB) pada bidang pertanian [3]. Hasil studi lain terkait salah satu strategi kebijakan perencanaan tenaga kerja di masa Pandemi Covid-19 adalah penggunaan platform digital untuk meningkatkan produktivitas. Pada tahun 2020, Rapat Kerja Nasional (Rakernas) bidang pertanian memaparkan tigal hal upaya untuk memajukan pertanian Indonesia. Upaya-upaya tersebut adalah: (1) mengidentifikasi kebutuhan dan 
harapan petani di masing-masing daerah; (2) mengarahkan petani secara mandiri menyelesaikan permasalahan, dimana pemerintah memiliki andil dalam hal dukungan dan pendampingan; dan (3) mengintegrasikan teknologi dan modernisasi [4]. Penyaluran produk pertanian yang cukup panjang dari petani ke pengguna merupakan salah satu permasalahan produk pertanian [5]. Penerapan Teknologi Informasi dan Komunikasi (TIK) dapat digunakan pada sistem informasi pemasaran pertanian.

TIK berperan strategis dengan pengaruh yang positif dalam aktivitas pemasaran pertanian Indonesia [6]. Dengan teknologi tersebut, akses pasar meningkat karena informasi secara luas, real-time dan cepat tersedia di internet. Tambahan, sistem informasi dapat mempercepat pengambilan keputusan baik bagi penyalur maupun pengguna. Sistem informasi pemasaran di bidang pertanian digunakan untuk menghimpun, memproses dan mendistribusikan informasi mengenai kondisi dan dinamika pada pasar pertanian [7]. Sistem informasi pertanian saat ini sangat terbatas dan belum banyak dikenal para petani. Sistem informasi mengenai ketersediaan barang, harga, dan produsen bahan pertanian masih sangat kurang. Selain itu kurangnya sumber informasi di sektor pertanian menjadi penghambat proses perolehan informasi di era digital saat ini [8]. Berdasarkan permasalahan tersebut, maka perlu dikembangkan suatu sistem informasi berbasis web yang berisi informasi hasil pertanian yang menyediakan akses secara langsung bagi para petani [9].

Beberapa penerapan teknologi di bidang pertanian diantaranya adalah: (1) sistem informasi untuk mengatasi kekurangan pendistribusian informasi pertanian kepada petani dari peneliti [10]; (2) sistem informasi untuk kemudahan informasi pengguna menggunakan android [8]; (3) sistem informasi untuk kemudahan dan kelengkapan informasi hasil pertanian berbasis website [11]; (4) marketplace berbasis e-commerce dapat memperpendek penyaluran produk pertanian
[5]; (5) sistem informasi pemasaran pertanian untuk melakukan transaksi pertanian dalam memasarkan hasil kepada pelanggan secara terpercaya dan efektif [12]; dan (6) pemasaran berbasis digital berisi informasi pengadaan bahan produksi sampai dengan pemasaran hasil produksi pertanian [13]. Berbagai penelitian terkait informasi pemasaran pertanian tersebut menggunakan berbagai platform digital dengan produk pertanian dan subjek kelompok produsen yang beragam.

Kabupaten Gowa, tepatnya di Desa Kanreapia memiliki potensi pertanian hortikultura yang memerlukan pemasaran yang lebih luas [14]. Pandemi COVID-19 yang saat ini melanda dunia, termasuk Indonesia serta merta mengubah pola kehidupan masyarakat. Adanya pembatasan sosial berskala besar (PSBB) salah satu yang menyulitkan baik petani maupun masyarakat pada umumnya yaitu terkait kegiatan jual beli. Penelitian ini bertujuan untuk mengembangkan sistem informasi pemasaran bidang pertanian yang dapat membantu para petani dan masyarakat (pengguna) untuk mendapatkan informasi dan melakukan pemesanan produk pertanian untuk memenuhi kebutuhan pokok masyarakat. Produk pertanian yang dimaksud adalah produk pertanian di Desa Kanreapia.

\section{METODE}

Penelitian ini menggunakan pendekatan Research and Development (R\&D). Penelitian $R \& D$ bertujuan menghasilkan produk tertentu serta menguji efektivitas produk tersebut [15]. Produk yang dihasilkan adalah aplikasi Pemasaran hasil pertanian Kota Gowa, dengan model pengembangan prototype. Teknik prototyping dalam pengembangan sistem informasi merupakan teknik yang dapat digunakan secara cepat untuk mengembangkan informasi tertentu mengenai syarat-syarat informasi pengguna [16]. Melalui teknik prototyping, pengembang dapat mengumpulkan informasi dari pengguna. Hal ini dikarenakan pengguna dapat berinteraksi dengan versi awal 
dari sistem berupa model prototype yang kemudian dapat dikembangkan lebih lanjut menjadi sistem sesungguhnya [17]. Pendekatan prototype yang digunakan dalam penelitian ini dapat dilihat pada Gambar 1.

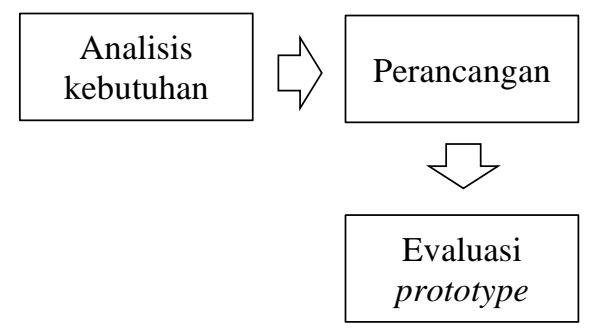

Gambar 1. Tahapan Pendekatan Prototyping

Pendekatan prototyping pada Gambar 1 terdiri atas tiga proses yaitu analisis kebutuhan, perancangan, dan evaluasi prototype [18]. Pada tahap analisis kebutuhan, pengembang dan klien bertemu untuk menentukan tujuan umum, menganalisis kebutuhan yang sudah diketahui dan yang kemungkinan kebutuhan lainnya. Pada tahap perancangan mewakili rancangan semua aspek software yang diketahui dan rancangan ini menjadi dasar pembuatan prototype. Selanjutnya pada tahap evaluasi prototype, klien akan mengevaluasi prototype atau versi awal dari produk yang dikembangkan, hasil evaluasi ini digunakan untuk memperjelas kebutuhan pengembangan produk selanjutnya.

Pengujian merupakan proses menguji semua elemen-elemen perangkat lunak yang dibuat, yang mana pengembang melihat apakah sudah sesuai dengan yang diharapkan. Pengujian ini dilakukan secara berkesinambungan dengan mengevaluasi fitur-fitur yang ada di perangkat lunak. Sistem Informasi Pemasaran Hasil pertanian Desa menggunakan metode uji kelayakan standar ISO/IEC 9126 [8].

Wawancara dilakukan sebagai studi pendahuluan untuk mendengar tanggapan Petani dan masyarakat Desa Kanreapia yang bertujuan memperoleh data yang berkaitan dengan informasi apa saja yang ingin dimasukkan dalam Aplikasi Pemasaran Hasil Pertanian. Sedangkan uji kelayakan aplikasi untuk aspek usability menggunakan kuesioner yang dibagikan kepada pengguna akhir (end user) aplikasi yaitu petani dan masyarakat. Jumlah pengguna akhir aplikasi untuk uji kelayakan sebanyak 10 petani dan 15 masyarakat dengan total 25 orang.

\section{HASIL DAN PEMBAHASAN}

Sistem informasi pemasaran hasil pertanian yang dirancang mencakup produk baru atau lepas panen, varietas produk dan jumlah produk. Tampilan sistem dapat dilihat dari tiga sudut pandang yang berbeda yaitu dari sisi Admin, Petani, dan Pembeli. Gambar 2 merupakan tampilan login admin. Basis data yang digunakan dalam sistem digambarkan dalam bentuk Entity Relationship Diagram (ERD). ERD merupakan kegiatan penggambaran basis data yang dimodelkan dalam suatu diagram yang nantinya digunakan untuk mendokumentasikan data dengan cara menentukan apa saja yang terdapat dalam tiap entity dan bagaimana hubungan entity [19]. Diagram ERD dari sistem informasi pemasaran hasil pertanian ditunjukkan pada Gambar 3 . Selanjutnya tampilan Home atau beranda seperti terlihat pada Gambar 4. Sistem ini menampilakan gambar padi yang menandakan bahwa sistem ini adalah sistem yang akan digunakan di dalam konsep pertanian, selain itu ada pula logo keranjang berisi buah-buahan sebagai penanda bahwa sistem ini akan digunakan pada transaksi penjualan. Tampilan menu home pada Admin memiliki banyak menu untuk mengatur sistem penjualan. Ketika halaman utama muncul maka akan dilihat menumenu yang dapat diakses yaitu kategori, satuan, barang, penjual, pembeli, penjualan, pesan, laporan. Setiap menu pada admin terdapat pilihan untuk menambah data, menghapus data, merubah data, dan menyimpan data.

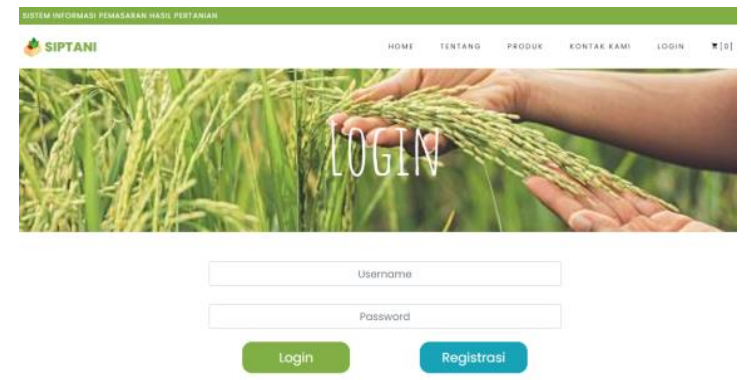

Gambar 2. Tampilan Login Admin 


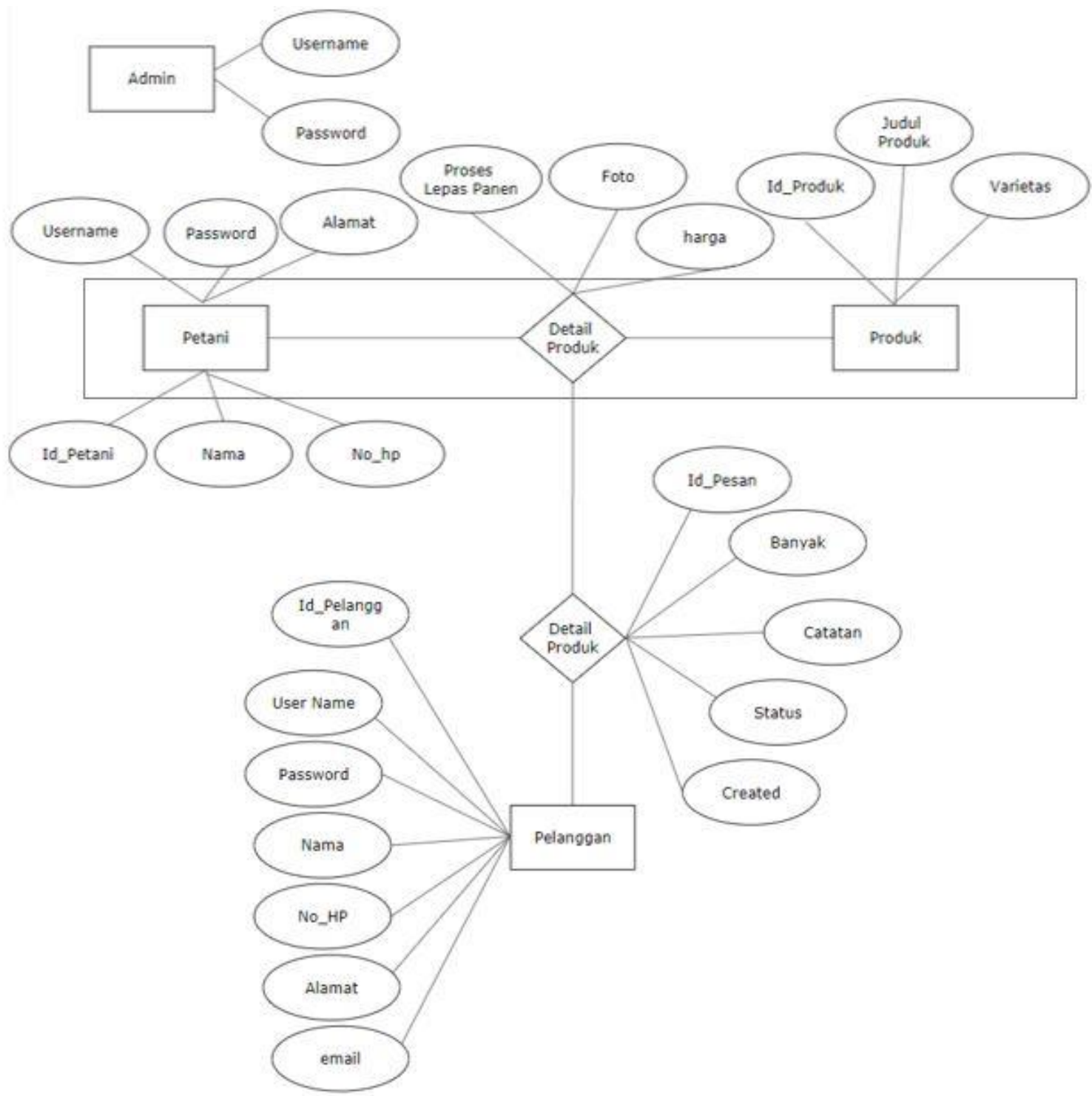

Gambar 3. Entity Relationship Diagram Sistem

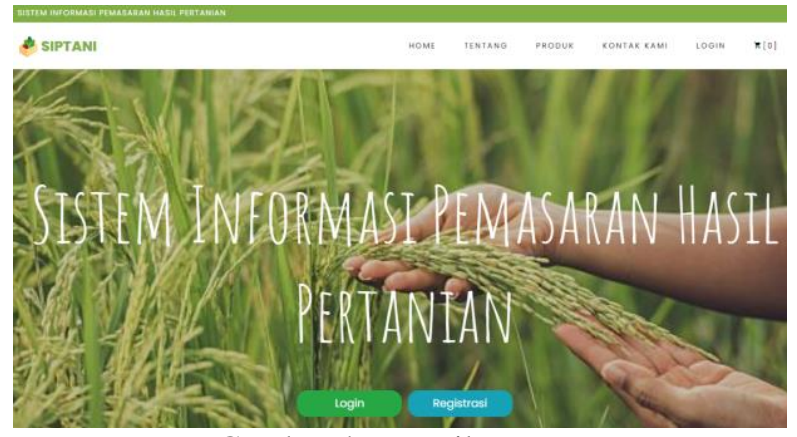

Gambar 4. Tampilan Home

Tampilan halaman barang berisi data-data barang yang dapat dijual pada sistem ada pada Gambar 5. User penjual dapat mengedit barang yang dijual dalam sistem. Untuk mengisi data barang maka dibutuhkan informasi dari penjual seperti Foto Produk, Nama Barang, Kategori, Jumlah Produk, Harga Produk. Pada menu ini penjual harus menunggu verifikasi produk yang benar dari admin.

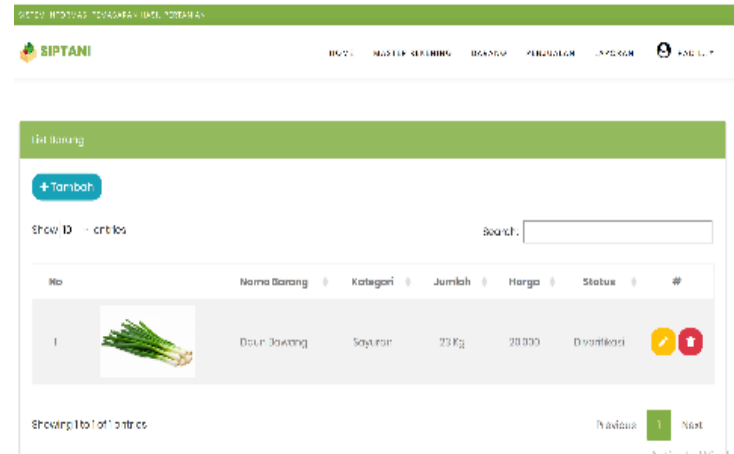

Gambar 5. Tampilan Halaman Barang 
Pada halaman penjualan yang dapat dilihat di Gambar 6, penjual dapat melihat pesan dari pembeli dan juga dapat mengkonfirmasi transaksi dalam sistem. Selain itu penjual juga dapat membatalkan transaksi melalui menu ini. Pada halaman laporan seperti pada Gambar 7, penjual dapat melakukan monitoring transaksi yang masuk dalam sistem sesuai dengan tanggal atau bulan dalam bentuk cetakan. Selanjutnya pada halaman Profil seperti Gambar 8, penjual dapat mengedit data dalam sistem ini.

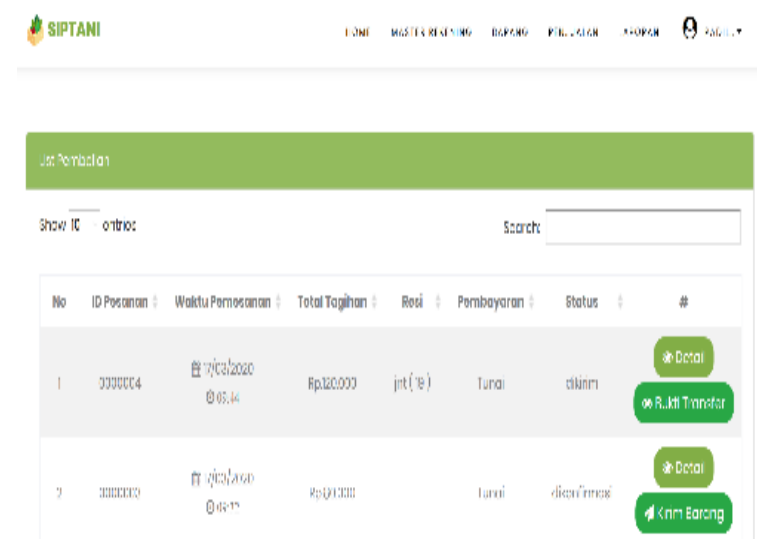

Gambar 6. Tampilan Halaman Penjualan
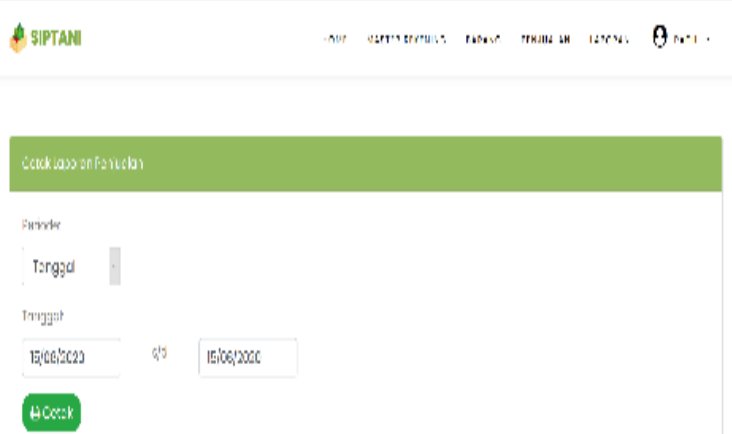

Gambar 7. Tampilan Halaman Laporan

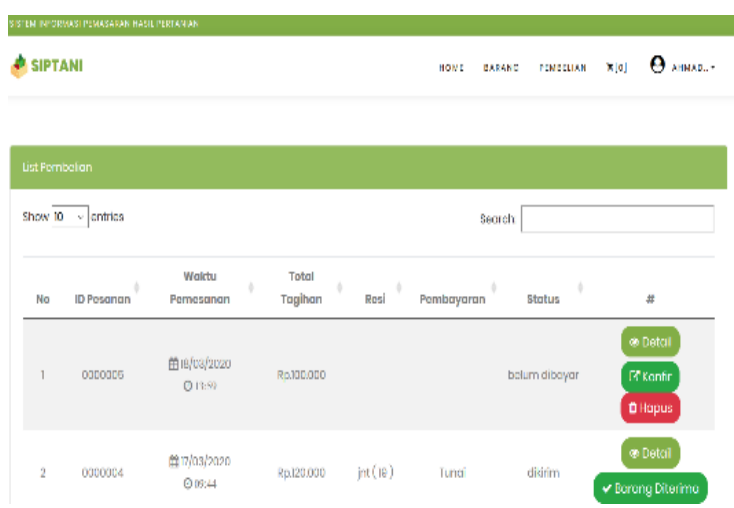

Gambar 8. Tampilan Profil Penjual
Pada halaman pembelian seperti pada Gambar 9, pembeli dapat melihat jenis barang/produk sesuai yang telah dipesan oleh pembeli,dan dalam menu ini pembeli bertransaksi dengan penjual barang. Tetapi dalam proses pesanan barang yang ingin dipesan hanya dapat pesan di satu toko terlebih dahulu sampai selesai transaksi, setelah selesai transaksi baru dapat melakukan pembelian di toko lain. dan juga dapat membatalkan pesanan.

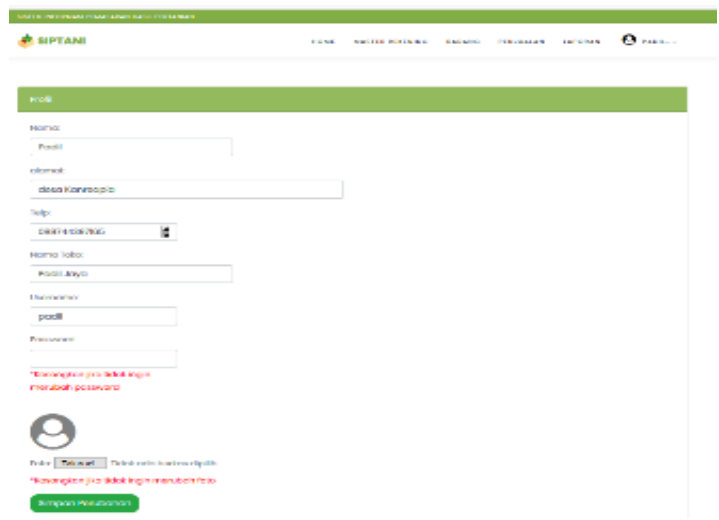

Gambar 9. Tampilan Pembelian

Setelah sistem berhasil dikembangkan, berikutnya dilakukan pengujian. Membuat sistem dapat diperasikan di berbagai platform tersebut memudahkan akses pengguna [20]. Salah satu tahapan pengembangan perangkat lunak adalah pengujian sistem [21]. Tujuan dari pengujian sistem adalah untuk memvalidasi perangkat lunak danu memastikan bahwa sistem memiliki keunggulan yang seharusnya dimiliki [12]. Pengujian memiliki peran penting dalam menghasilkan sistem informasi pemasaran pertanian yang dapat digunakan dengan baik oleh pengguna.

International Organization for Standarization (ISO) dalam ISO Standard 9126 telah mengusulkan beberapa karakteristik untuk melakukan pengujian terhadap kualitas sebuah perangkat lunak [22]. Terdapat enam karakteristik yang ada pada pengukuran ISO 9126 yakni karakteristik functionality, usability, reliability, efficiency, portability dan maintainability [23]. Selain itu, Web Quality Evaluation Method (WebQEM) [3] mengusulkan beberapa karakteristik untuk 
melakukan pengujian terhadap aplikasi web. Olsina mengidentifikasikan empat karakteristik dari sisi pengguna yaitu functionality, efficiency, reliability, dan usability [22] The ISO standard, defines three views of quality: users' view, developers' view, and managers' view [24]. Faktor yang menjadi high level quality ada empat faktor yaitu: usability, functionality, reliability dan efficiency [25]. Lebih lanjut, pengujian dalam penelitian ini dilakukan dengan mengambil masing-masing dua karakteristik pada pengujian ISO 9126 yaitu karakteristik kualitas eksternal (functionality dan usability) dan dua karakteristik kualitas internal yaitu maintanibility dan portability. Hasil uji functionality oleh dua ahli media/sistem dapat dilihat pada Tabel 1.

Tabel 1. Rekapitulasi Skor Penilaian Functionality

\begin{tabular}{|c|c|c|c|}
\hline \multirow[t]{2}{*}{ Validator } & $\begin{array}{l}\text { Jumlah } \\
\text { fitur yang } \\
\text { di desain }\end{array}$ & $\begin{array}{l}\text { Jumlah } \\
\text { fitur } \\
\text { yang } \\
\text { berhasil } \\
\text { diuji }\end{array}$ & \multirow[t]{2}{*}{$\begin{array}{c}\text { Feature } \\
\text { Completenes }\end{array}$} \\
\hline & (I) & (P) & \\
\hline $\begin{array}{c}\text { Ahli } \\
\text { Sistem } 1\end{array}$ & 81 & 81 & 1 \\
\hline $\begin{array}{c}\text { Ahli } \\
\text { Sistem } 2\end{array}$ & 81 & 81 & 1 \\
\hline Rata-rata & 81 & 81 & 1 \\
\hline
\end{tabular}

Pengujian aspek functionality dilakukan dengan menguji fungsionalitas aplikasi oleh validator ahli. Penilaian aspek ini dilakukan secara langsung dengan melakukan cek satu persatu fungsionality dari bagian-bagian pada aplikasi. Instrumen pengujian functionality berisi 81 test factor, jika fungsi aplikasi berjalan atau sesuai dengan test factor maka nilai yang diberikan adalah "1", dan jika tidak sesuai atau tidak berfungsi maka nilai yang diberikan adalah "0" dimana Nilai 1 berarti "Ya" dan nilai 0 berarti "Tidak". Cara memilih kategori Ya/Tidak yaitu dengan memberikan checklist pada salah satu pilihan yang sesuai.

Pengujian karakteristik functionality dikatakan baik jika $X$ mendekati 1 [26]. Tabel 1 menunjukkan bahwa skor rerata uji functionality adalah sebesar 1. Berdasarkan hasil pengujian tersebut maka aplikasi yang dikembangkan berada pada kategori Baik dan telah memenuhi aspek functionality. Pengujian aspek usability dilakukan dengan membagikan angket kepada pengguna. Hasil dari pengujian aspek usability menunjukkan bahwa sistem pemasaran mendapatkan tanggapan baik dari responden dengan prosentase sebesar $88,13 \%$. Uji usability ini penting dilakukan agar tidak diperoleh penolakan oleh pengguna akibat penilaian yang buruk terkait penggunaan sistem [27]. Dengan hasil uji usability tersebut menunjukkan bahwa sistem memiliki fitur-fitur yang dapat digunakan dengan baik. Pengujian aspek maintanability dilakukan secara operasional sesuai instrumen versi Rikard Land. Hasil pengujian aspek tersebut dapat dilihat pada Tabel 2.

Tabel 2. Pengujian Maintability

\begin{tabular}{|c|c|c|c|}
\hline No & Pernyataan & $\begin{array}{l}\text { Sub- } \\
\text { karakteristik }\end{array}$ & Hasil Pengujian \\
\hline 1 & $\begin{array}{l}\text { Kemudahan dalam diagnosis } \\
\text { kesalahan fungsi program }\end{array}$ & Analyzability & $\begin{array}{l}\text { Ketika ada kesalahan oleh user maka sistem } \\
\text { mengeluarkan peringatan kesalahan. }\end{array}$ \\
\hline 2 & $\begin{array}{l}\text { Kemudahan dalam } \\
\text { pengelolaan, perbaikan, dan } \\
\text { pengembangan aplikasi. }\end{array}$ & Changebility & $\begin{array}{l}\text { Ketika ada perubahan data dilakukan oleh } \\
\text { user maka sistem dapat menyimpan hasil } \\
\text { perubahan data. }\end{array}$ \\
\hline 3 & $\begin{array}{l}\text { Dapat berjalan dengan baik } \\
\text { setelah dilakukan revisi. }\end{array}$ & Stability & $\begin{array}{l}\text { Sama halnya dalam pengujian sebelumnya } \\
\text { sistem dapat membaca revisi perubahan data } \\
\text { dari user dan berjalan dengan lancar kembali. }\end{array}$ \\
\hline
\end{tabular}

Pengujian maintainability membantu dalam optimalisasi pemanfaatan sumber daya dalam sistem [28]. Hasil ketiga uji pada Tabel 2 diperoleh bahwa, sub aspek analyzability, changebility, dan stability dalam kondisi sesuai dengan perencanaan yang diharapkan. Hal 
tersebut menunjukkan bahwa terdapat beberapa langkah sebagai upaya pemeliharaan perangkat lunak. Selanjutnya pengujian aspek portability dilakukan dengan menjalankan sistem melalui browser baik berbasis desktop maupun mobile. Pengujian yang dilakukan berbasis desktop antara lain menggunakan browser Mozilla Firefox, Internet Explorer, Opera, Yandex, dan Google Chrome. Pengujian ini dilakukan secara langsung dan juga secara simulasi menggunakan web. Hasil pengujian aspek portability pada semua browser hasilnya berjalan dengan baik. Dengan pengujian-pengujian yang telah dilakukan yaitu, uji functionality, usability, maintainability, dan portability menunjukkan bahwa sistem informasi berjalan dengan baik.

\section{SIMPULAN}

Sistem informasi pemasaran bidang pertanian ini digunakan sebagai media informasi dan pemasaran hasil pertanian berbasis website. Pada pengembangan aplikasi ini menggunakan model pengembangan prototyping. Aplikasi ini dikembangkan menggunakan software Xampp dengan bahasa pemograman HTML, PHP, dan Java. Sistem informasi pemasaran pertanian yang dikembangkan ini memiliki kualitas yang baik yang memenuhi aspek functionality, usability, maintability dan portability. Hasil dari pengujian yaitu: (1) skor rerata uji functionality adalah sebesar 1; (2) prosentase aspek usability adalah sebesar 88,13\%; (3) pengujian maintainability yang terdiri atas sub aspek analyzability, changebility, dan stability dalam kondisi sesuai dengan perencanaan yang diharapkan; dan (4) aspek portability melalui penggunaan sistem di browser Mozilla Firefox, Internet Explorer, Opera, Yandex, dan Google Chrome menunjukkan sistem berjalan dengan baik. Sedangkan untuk aspek efficiency dan reliability perlu dilakukan beberapa perbaikan pada sistem. Pengembang selanjutnya diharapkan dapat mengembangkan sistem ini menjadi lebih interaktif antar penjual dan pembeli.

\section{DAFTAR PUSTAKA}

[1] R. F. Widyawati, “Analisis Keterkaitan Sektor Pertanian Dan Pengaruhnya Terhadap Perekonomian Indonesia (Analisis Input Ouput)," J. Econ., vol. 13, no. 1, p. 14, 2017.

[2] BPS, "Keadaan Ketenagakerjaan Indonesia Agustus 2020," Badan Resmi Stat., no. No.86/11/Th. XXIII, 2020.

[3] R. Sulistiawati, "Strategi Kebijakan Perencanaan Tenaga Kerja Pasca Pandemic COVID-19 Dalam Perspektif Revolusi Industri 4.0 di Provinsi Kalimantan Barat," in Prosiding Seminar Akademik Tahunan Ilmu Ekonomi dan Studi Pembangunan 2020, 2020, pp. 114129.

[4] K. P. RI, "Mentan Syahrul Paparkan Terobosan Majukan Pertanian," Kementerian Pertanian Republik Indonesia, 2020. .

[5] D. Apriadi and A. Y. Saputra, "ECommerce Berbasis Marketplace Dalam Upaya Mempersingkat Distribusi Penjualan Hasil Pertanian," J. RESTI (Rekayasa Sist. dan Teknol. Informasi), vol. 1, no. 2, pp. 131-136, Oct. 2017.

[6] H. Akhmadi, "Use of Information and Communication Technology (ICT) on Agricultural Marketing in Indonesia a Brief Literature Review," in Proceedings of the International Conference on Food, Agriculture and Natural Resources (FANRes 2018), 2018, pp. 283-286.

[7] F. Galtier, H. David-Benz, J. Subervie, and J. Egg, "Agricultural market information systems in developing countries: New models, new impacts," Cah. Agric., vol. 23, no. 4-5, pp. 232-244, Jul. 2014.

[8] M. Olivya and Ilham, "Sistem Informasi Pemasaran Hasil Pertanian Berbasis Android," Inspir. J. Teknol. Inf. dan Komun., vol. 7, no. 1, pp. 60-69, 2017.

[9] S. Rahayu, R. Cahyana, and S. S, "Perancangan Sistem Informasi Hasil Pertanian Berbasis Web Dengan Unified Approach," J. Algoritm., vol. 16, no. 2, pp. 96-103, 2019.

[10] N. Kizilaslan, "Agricultural information systems: a national case study," Libr. Rev., vol. 55, no. 8, pp. 497-507, Oct. 2006. 
[11] N. Aprini, "Perancangan Sistem Informasi Pemasaran Hasil Pertanian Berbasis Web di Kota Pagar Alam," J. Inform., vol. 7, no. 2, pp. 13-24, 2019.

[12] A. Umar, I. U. Kontagora, H. S. Kuta, and N. Umar, "Agricultural Marketing Information System," Int. J. Res. Sustain. Dev., vol. 7, no. 1, pp. 50-64, 2020.

[13] N. Anggraini, Sutarni, C. Fatih, M. Zaini, Analianasari, and E. Humaidi, "Digital Marketing Produk Pertanian di Desa Sukawaringin Kecamatan Bangunrejo Kabupaten Lampung Tengah," $J$. Pengabdi. Nas., vol. 1, no. 1, pp. 36-45, 2020.

[14] J. D. Abu, "Hortikultura Menjadi Potensi Desa Kanreapia," Kedesa.ID, 2017. .

[15] Sugiono, Metode Penelitian Manajemen. Pendekatan kualitatif, Kuantitatif, Kombinasi. Bandung: Alpabeta, 2016.

[16] E. Ali, "Sinergi Pendekatan Prototyping Dalam Mengembangkan Perangkat Lunak Pelayanan Pasien (Studi Kasus pada RSUD Siak)," SATIN - Sains dan Teknol. Inf., vol. 1, no. 2, pp. 63-73, 2012.

[17] D. Purnomo, "Model Prototyping Pada Pengembangan Sistem Informasi," J I M $P$ - J. Inform. Merdeka Pasuruan, vol. 2, no. 2, pp. 54-61, 2017.

[18] R. S. Lugina, "Rancangan Bangun Multimedia Pembelajaran Dengan Berbantu Metode Explicit Instruction," Univ. Pendidik. Indones., vol. 53, no. 9, pp. 1689-1699, 2019.

[19] N. D. Prasetyo, D. Supratman, W. A. H. Fauzi, and S. Murti, "Perancangan Sistem Informasi E-Farming Berbasis Web untuk Mengetahui Tingkat Kelayakan Panen pada Sektor Pertanian," Semin. Nas. Apl. Teknol. Inf., pp. 7-12, 2016.

[20] R. Nori, N. Karodiya, and H. Reza, "Portability testing of scientific computing software systems," in IEEE International Conference on ElectroInformation Technology, EIT 2013, 2013, pp. 1-8.

[21] E. R. Subhiyakto and D. W. Utomo, "Software Testing Techniques and Strategies Use In Novice Software Teams," Sisfo, vol. 05, no. 05, pp. 556562, Mar. 2016.

[22] T. N. Sari, "Analisis Kualitas Dan Pengembangan Sistem Informasi Akademik Berbasis Web Menggunakan
Standard Iso 9126," JIKO (Jurnal Inform. dan Komputer), vol. 1, no. 1, pp. 1-7, 2016.

[23] I. Sopian, U. P. Indonesia, S. Pengelolaan, P. Alam, and U. Pendidikan, "Implementasi Dan Pengujian Sistem Informasi Tracer Study Berbasis Web Menggunakan Standard Iso / Iec 9126 ( Studi Kasu: Fakultas Pendidikan Matematika Dan Ilmu Pengetahuan Alam - Upi )," J. Teknol. Inf. dan Komun., vol. VIII, no. 2, 2018.

[24] L. Olsina, G. Lafuente, and G. Rossi, "Specifying Quality Characteristics and Attributes for Websites," pp. 266-278, 2001.

[25] M. Veronica, D. Antoni, and M. Akbar, "Adopsi Website Quality Evaluation Method (WebQem) dan Iso 9126 untuk Mengukur Service Quality pada Ujian Online," J. Teknomatika, vol. 08, no. 01, pp. 23-32, 2018.

[26] S. Anugrah and A. E. Putra, "Analisis Kualitas ISO 25010 Aplikasi Artificial Intelligence Troubleshooting Komputer dengan FURPS," E-Tech J. Ilm. Teknol. Pendidik., vol. 6, no. 2, 2018.

[27] R. Kruger, J. Brosens, and M. Hattingh, "A Methodology to Compare the Usability of Information Systems," in Nature Public Health Emergency Collection, 2020, pp. 452-463.

[28] R. Malhotra and A. Chug, "Software Maintainability: Systematic Literature Review and Current Trends," Int. J. Softw. Eng. Knowl. Eng., vol. 26, no. 08, pp. 1221-1253, Oct. 2016. 